different meteors. This year, on August ro, in bright moonlight, I traced five meteors from $6^{\circ}+37^{\circ}$, and the epoch and place fall near Comet Ir. 1780 , August $14,3 \frac{1}{2}^{\circ}+38 \frac{1}{2}^{10}$, but the comet was only visible for three days after its discovery by Montaigne and others on November $28, \mathrm{x} 780$, and hence the orbit is not likely to have been exactly determined. At the nodal passage the comet's orbit lies far within the orbit of the earth, so that an encounter of the earth with the comet-particles is only possible on the thesis of Weiss and Schiaparelli that "some part of the cometary materials repelled from its proper orbit by the sun in the form of the tail or other Iuminous appendage emitted by the comet near its perihelion passage extends to such a distance in its orbital plane as to intersect the orbit of the earth" (see B.A. Report, 1873, pp. 4or-2).

Ashleydown, Bristol, September $\mathbf{I} 6$

\section{W. F. DENNing}

\section{The Zoological Record}

IN the third number of vol. iii. of the Niederländisches Archiv fiir Zoologie (Leiden: E. T. Brill), I published in German a "Catalogue Raisonné" of zoological works and papers that appeared in the Netherlands during 1875 and 1876 . You noticed the appearance of this paper in your "Notes" (NATURE, vol. xvi, p. II2).

The principal reason of my publishing this bibliography was my wish to make known in other countries what is done in the Netherlands in the zoological department. For the same pur. pose, about the end of May, I877, I sent a copy of my paper to the Zoological Record and addressed it "Solely to the Editor of the Zoological Record, care of Mr. Van Voorst, I, Paternoster Row, London."

Afterwards studying vol, xii. and xiii. of the said "Record," I found that about twenty of the papers recorded in my catalogue were not mentioned in these volumes. Of course this might have been occasioned by the mimportance of these twenty tunlucky papers; but conscientionsly comparing their value with that of the other sixty of my bibliography, and as far as possible in general with the papers mentioned in the Record $Y$ got the conviction that this could not be the reason.

I feel a great deal of admiration, and at the same time of gratitude for the immense amount of work done by the contributors of the Record, and I quite agree with you (NATURE, vol. xviii. $\mathrm{p}, 485$ ) that it would be to the everlasting disgrace of zoologists (not only of your tongue, but of all tongues) if its existence should be premattrely brought to a close. But only when I find in the Record as much completeness as possible, the use of it will spare me the endless trouble of looking for every detail over the totality of zoological literature.

Now I don't believe that in the case mentioned here (to secure this completeness) much care has been taken.

September 19

\section{P. P. C. HOEX}

\section{Earth Pillars}

SHOULD you deem the following of sufficient interest, will you kindly insert it in NATURE?

A few days since I saw an interesting example of minute earth-pillars on the shore of the Hecht Sea, above Kiefersfelden, Inn Thal. In a cove to the north the beach for many yards formed a perfect forest of little pillars, whose height ranged from a quarter to three-quarters of an inch. On the top of most lay a small stone, a fragment of wood or shell; but some, which had lost their coverings, were wearing away. The shell fragments (from a Unio, I fancy) seemed to form the most complete protection, and these often fitted the pillars like helmets; in fact, it required no great stretch of the imagi. nation to fancy the whole a marching army, and the jutting wood fragments spears.

South Tyrol is by no means the only place in this country where earth-pillars occur, though the Bozen pillars are probably the finest. Among'st others in North Tyrol there is a very interesting example of large earth-pillars on the Brenner railway, between Innsbruck and Patsch, on the right-going south

Brixlegg am Inn, Tyrol, September I 7,1878 JAMES H. MIDGLEY

\section{Indian Building Timber}

IN NATURE, vol, xviii. p. 3I the wood used in Peking in building houses, temples, and palaces is said to come from Corea;" it is further remarked editorially, "we think, however, our contemporary is in error in stating, without qualification, that 'the great wooden masts which support the noble temples and gatehonses of the Imperial City of Peking (all enormous, beautiful, and enduring spars) come from Corea."

Having had some experience in the timber and timber-trees of Burma I am inclined to the opinion that this valuable timber "nan-mu" therein referred to will prove to be identical with the wood used for the same purposes generally over Burma. The wood is called in Lower Burma "Pyenkadoo," it has a wide distribution under a variety of names, according to the different provincial dialects of the districts it is found in. Its great length of bole without branches, the different sizes at which it can be obtained renders it from its great durability, readiness to polish, and its variegated and coloured grain (brown mahogany colour) most suitable for the supports or pillars of "lkyoings," or temples. It belongs to the natural order Leguminosex, specific name Inga xylocarpa.

Besides this there are several other woods highly esteemed by the Burmese for durability, and these chiefly are found amongst the Cassias and Dalbergias.

Inga xylocarpa has great toughness-a piece of three feet long by one inch square I find stood a breaking weight of $\mathrm{I}, \mathrm{I} 53$ pounds; its specific gravity is nearly double that of teak and it does not float.

The objection to the introduction of the different ornamental and useful timbers of Burma is their tonghness, hardness to work, and hence increased labour and wear of tools.

Whitby

R. BENSON

[With reference to the question of the identity of the wood of the "nan-muh" tree with that of $l n g a$ xylocarpa we may point out that from material received at Kew the former has been referred to a Lauraceous tree, probably Phabe pallida. From comparison of the two woods microscopically they present something in common, the annual rings, however, are much more apparent in the "nan-mub" than in the "Pyenkadoo." This latter is of a dark reddish brown, extremely heavy, as described by Col. Benson, while the nan-muh is of a dull umber colour and much lighter in weight.-ED.]

\section{OUR ASTRONOMICAL COLUMN}

THE INTRA-MERCURIal Planet.-The particulars of Mr. Lewis Swift's observations during the totality of the recent eclipse, given in his letter which appeared in NATURE last week, are satisfactory so far as they afford independent testimony to the existence of an unknown body in the vicinity of the star $\theta$ Cancri, or in the locality where Prof. Watson, a few minutes previously, had observed an object which he considers to have been an intra-Mercurial planet. In other respects Mr. Swift's letter is indefinite and contradictory in itself. He tells us that he observed two red stars "with large, round, and equally bright discs," estimating the distance between them at about $7^{\prime}$ or $8^{\prime}$; and, one of the objects being identified with $\theta$ Cancri, he intimates that the proximity of the other to this star enabled him to estimate its position with great exactness, especially in declination. But in a subsequent paragraph, where the place of the star is adopted from the Astronomer-Royal, the unknown object is fixed to a position which makes its distance from $\theta$ Cancri $30^{\prime}$, or four times as great as mentioned previously. The place of the supposed planet, according to Prof. Watson, was, as stated last week, in right ascension $8 \mathrm{~h} .27 \mathrm{~m} .24 \mathrm{~s}$, , and declination $18^{\circ} 16^{\prime} \mathrm{N}$.; and as the apparent place of the star at the time was in right ascension $8 \mathrm{~h} .24 \mathrm{~m} .39^{\circ} 9^{5}$., and declination $18^{\circ} 30^{\prime} \mathrm{I} 9^{\prime \prime}$, the distance between the two was $42^{\prime}$, on an angle at the star, of $110^{\circ}$. With regard to Mr. Swift's concluding observation as to the position of the presumed planet in its orbit, it is evident that, to present a round or nearly round disc, it must have been situate, as Prof. Watson infers, in the superior part of the orbit, and being to the west of the sun, would be approaching superior conjunction.

Prof. Watson states that the magnitude of the object in question was 4 to $4 \frac{1}{2}$, and that of the second unknown star, which he alone appears to have observed, was $3 \frac{1}{2}$, and adds, "they were probably really brighter, because 
the illumination of the sky was not considered in the estimates." Before he entered upon the reduction of his observations, he had thought the second object might be $\zeta$ Cancri (though surprised to find it so bright) because he did not see that star-a well-known double star, components $5 \frac{1}{2}$ and $6 \frac{1}{2},-$ a gust of wind which occurred just before the end of totality having possibly disturbed the telescope. Yet, the circumstance of his not having remarked $\zeta$ Cancri would be accounted for by his statement that he did not sweep further than the second object, which his reading places in right ascension $8 \mathrm{~h} .9 \mathrm{~m} .24 \mathrm{~s}$., declination $18^{\circ} 3^{\prime}$, and which he believes to be correct-the sun coming out immediately afterwards, and of course putting an instantaneous termination to his observations.

VARIABLE STARS.-The following are the Greenwich times of geocentric minima of Algol and S Cancri in the last quarter of the present year, which fall between dusk and $\mathrm{I} 3 \mathrm{~h}$. M.T.

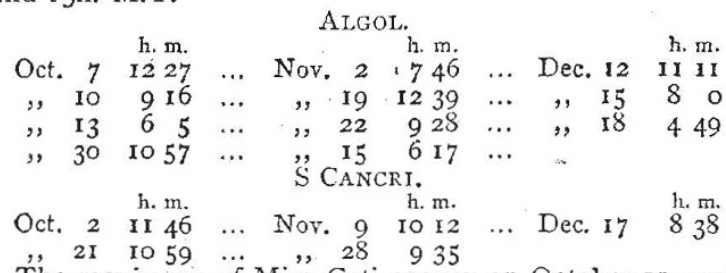

The maximum of Mira Ceti occurs on October $I x$, and the minimum of $\chi$ Cygni on October 26, according to Prof. Schönfeld.

Tine Meteor of December 24, I 873.-Mr. Cleveland Abbe, Director of the Observatory of Cincinnati, sends us a discussion of the observations of a remarkable meteor seen on Christmas Eve, 1873 , to which the attention of the Washington Philosophical Society had been particularly directed soon after its occurrence, and, on the suggestion of the late secretary of the Smithsonian Institution, a committee formed with the view of collecting and discussing observations. Though about fifty accounts of the appearance of the meteor were thus brought together, they have only sufficed to give a general idea of its track and altitude. Nearly all the observers describe it as equalling the full moon in brightness, with conical form moving base forward, but not followed as in so many cases, by any regular train; colour bright yellow, sparks or flames of red and blue proceeding from it. Mr. Abbe finds that it "entered the earth's atmosphere at some point vertically above the northern part of the State of Delaware, so that its apparent altitude, as seen at Danbury, Conn., was $30^{\circ}$, and at Washington, D.C., about $45^{\circ}$," whence he concludes its real altitude above the earth's surface to have been about ninety miles. Its after-course was downward to beyond Fairfax county, and at its nearest approach to the earth it was distant twenty miles. Its entire visible path of about 120 miles was described in from three to five seconds. An explosion occurred at a distance of about thirty miles from Washington, where the meteor was observed, amongst others, by Profs. Newcomb, Hilgard, and Holden.

\section{MR. THOMAS GRUBB, F.R.S.}

WE regret to announce the death of $\mathrm{Mr}$. Thomas Grubb, F.R.S., and we cannot do so without referring to his marked talents and the important service he has rendered to science.

Mr. Grubb was originally intended for a mercantile career, but his natural tastes proved too strong to allow him to continue in the life he had begun. He became a mechanical engineer, and soon his workshops became known not only for excellent workmanship but still more for marked originality of conception in design. His chef-d'wuvre in both these respects is probably the machinery for engraving, printing, and numbering the notes of the Bank of Ireland.

Whilst Mr. Grubb's workshops were rising in reputation, he was quietly and steadily developing marked powers as a practical optician. During the construction of the great 6-feet equatorial at Parsonstown, the late Lord Rosse frequently acknowledges his obligations to Mr. Grubb for valuable suggestions. The system of levers on which Lord Rosse supported his specula, to avoid flexure, was of Mr. Grubb's invention. Of his chief scientific works we may mention :-

I. The equipment of nearly forty British magnetic stations under the direction of Provost Loyd.

2. A I5-inch reflecting telescope equatorially mounted at the Armagh Observatory.

3. The equatoreals of the Markree and Dunsink Observatories-refractors of 13 and 12 inches aperture respectively. And lastly, the great Melbourne telescope of 4 feet aperture, equatorially mounted, and driven by clockwork. After this last achievement Mr. Grubb retired from business life, succeeded by his son, $\mathrm{Mr}$. Howard Grubb.

Such works as the 15 -inch refractors in the observatories of Lord Lindsay and Dr. Huggins, and the great refractor of 27 inches aperture now in course of construction for Vienna show that the son is no unworthy representative of the father.

Mr. Thomas Grubb was elected a Fellow of the Royal Society of London in 1864 , in recognition of his successful completion of the great Melbourne telescope, and of his other successful labours in the cause of science. He was also a member of the Royal Irish Academy. He died on the roth instant at his residence in Dublin, and leaves to mourn his loss a large circle of friends whom his kindly genial manners and ever interesting conversation had drawn round him.

\section{MR. THOMAS BELT, F.G.S.}

THE scientific world will hear with regret the recent death of the well-known naturalist and geologist, Mr. Thomas Belt, F.G.S., which has just been telegraphed from Colorado. It is believed to have been caused by mointain fever. Elected a Fellow of the Geological Society in 1866 , the geological world owes to him the division of the Lingula flags into Maentwrog, Ffestiniog, and Dolgelly flags, proposed in 1867 . In I874 appeared his well-known and deservedly popular "Naturalist in Nicaragua," in which he showed how his professional avocations as an engineer had lent keenness to his observing faculties, and how an acute reasoner can utilise his observations. The work conveyed much information on protective mimicry, plant-fertilisation, sexual selection, and the other collateral issues of the theory of evolution. It contained the first sketch of those views on glacial geology which were the most prominent subject of the author's study for the rest of his life. These views were given in considerable detail in the Geological Magazine for April, 1874, and were well expounded by Mr. Henry Woodward, F.R.S., in his presidential address of that year to the Geologists' Association. Mr. Belt skilfully answered his opponents in NATURE, vol: $x$. , his controversial speaking and writing being always marked by a candour and temper which, if it did not carry conviction, could not fail to elicit adniration from perfect strangers and mere spectators. In November, I875, he read a paper to the Geological Society "On the Drift of Devon and Cornwall" (Quart. 'Four. Geol. Soc., vol. xxxii.), and another "On the Steppes of Southern Russia" (Quart. Four. Geol. Soc., vol. xxxiii.), in June, 1877 . He also contributed various papers to the Quarterly foumal of Science, amongst others one "On the Loess of the Rhine and the Danube," in January, 1877, and one "On the Glacial Period in the Southern Hemisphere," in July, I 877. 